\title{
НЕЙРОГУМОРАЛЬНІ ПОРУШЕННЯ У ХВОРИХ НА ХРОНІЧНИЙ КОРОНАРНИЙ СИНДРОМ, КОМОРБІДНИЙ З НЕАЛКОГОЛЬНОЮ ЖИРОВОЮ ХВОРОБОЮ ПЕЧІНКИ
}

\author{
๑Н. С. Михайловська, Л. Є. Міняйленко, О. О. Лісова, Т. О. Кулинич, \\ А. В. Грицай, О. В. Шершньова, І. О. Стецюк
}

Запорізький державний медичний університет

РЕЗЮМЕ. Неалкогольна жирова хвороба печінки розглядається як один із асоційованих з метаболічним синдромом станів, що значно погіршує перебіг хронічного коронарного синдрому (ХKC).

Мета - вивчити рівні адипоцитокінів, маркерів системного запалення та ендотеліальної дисфункції та їх взаємозв'язок з клінічним перебігом ХКС, коморбідної з неалкогольною жировою хворобою печінки (НАЖХП).

Матеріал і методи. У проспективне моноцентрове подвійне відкрите дослідження в паралельних групах залучено 120 хворих на XКС: стабільну стенокардію напруження II-ІІІ функціонального класу віком 60,0 (55,0; 64,0) років, з них 67 (55 \%) чоловіки і 53 (45\%) жінки. До групи контролю увійшли 30 практично здорових осіб віком 59,0 (58,0; 66,0) років, серед них 14 (46 \%) чоловіків і 16 (54 \%) жінок). Визначення вмісту біомаркерів (адипонектину, резистину, інсуліну, асиметричного диметиларгініну (ADMA), С-реактивного протеїну) у сироватці крові виконувалося за допомогою імуноферментного аналізу.

Результати. У хворих на ХКС із НАЖХП похідні рівні біомаркерів вірогідно $(p<0,05)$ відрізнялись від показників групи контролю: концентрація резистину була на 48 \% вищою, адипонектину на 60 \% нижчою; спостерігалось збільшення вмісту СРБ (у 8,9 раза) та ADMA (на 42 \%). У хворих на ХKC без патології печінки рівні адипонектину і резистину суттєво не переважали аналогічні показники у здорових осіб, однак відзначено достовірно вищі рівні СРБ (у 3,1 раза) та ADMA (на 30 \%). У хворих на ХКС, поєднану з НАЖХП, порівняно з пацієнтами з ХКС без структурно-функціональної патології печінки, встановлено значне $(p<0,05)$ зменшення рівня адипонектину на $31,6 \%$, збільшення резистину на $27 \%$, ADMA на $21 \%$ та СРБ у 2,81 раза. У хворих з неалкогольним стеатогепатитом (НАСГ) активність системного запалення була вірогідно більшою, порівняно з хворими зі стеатозом, що підтверджувалось підвищенням концентрації СРБ на 44 \% $(p<0,05)$. Виявлені кореляції відображають взаємозв'язок функціонального стану печінки з метаболічними та нейрогуморальними порушеннями.

Висновки. У хворих на ХКС, асоційовану з НАЖХП, спостерігається дисбаланс адипоцитокінів (зменшення концентрації адипонектину, збільшення рівня резистину та зменшення співвідношення адипонектину до резистину) порівняно з контрольною групою та з хворими на ХКС без патології печінки. Достовірне зростання сироваткового рівня ADMA та СРБ свідчить про наявність дисфункції ендотелію на тлі активації системного запалення і може вказувати на патогенетичне значення цих маркерів у розвитку та прогресуванні ХКС на тлі НАЖХП.

КЛЮчОВІ СЛОВА: хронічний коронарний синдром; неалкогольна жирова хвороба печінки; адипонектин; резистин; інсулін; асиметричний диметиларгінін; С-реактивний протеїн.

Вступ. Хронічний коронарний синдром (ХКС) одна з найактуальніших проблем сучасної медицини, оскільки займає перше місце серед причин інвалідизації та смертності населення $[1,2]$. Поряд із ХКС важливою медико-соціальною проблемою $\epsilon$ захворювання шлунково-кишкового тракту, які у 60 \% випадків спостерігаються в осіб працездатного віку $[3,4]$. Найчастішою формою хронічної патології гепатобіліарного тракту $\epsilon$ неалкогольна жирова хвороба печінки (НАЖХП): її поширеність сягає $33 \%[5,6]$. Результати епідеміологічних досліджень свідчать про збільшення виявлення НАЖХП у пацієнтів з інсулінорезистентністю [7, 8], тому НАЖХП вважають печінковою складовою маніфестації метаболічного синдрому [9]. Жирова інфільтрація печінки виявляється у $90 \%$ пацієнтів із кардіоваскулярною патологією $[10,11,12]$. Відомо, що НАЖХП підвищує ризик виникнення серцево-судинних захворювань і збільшує смертність від них, незалежно від інших проявів метаболічного синдрому [13].

Одним із перспективних напрямків сучасної внутрішньої медицини $\epsilon$ пошук нових біологічних маркерів, які 6 мали незалежне прогностичне значення у хворих зі стабільними формами ХКС та супутньою патологією печінки. Серед них особлива увага приділяється гормонам жирової тканини адипонектину, що має антидіабетичну, антиатерогенну і протизапальну дію [14], а також резистину, який асоціюється із системним запаленням та інсулінорезистентністю [15]. Важливою патогенетичною ланкою між стеатозом печінки та ХКС вважають дисфункцію ендотелію [16]. Одним із сучасних маркерів дисфункції ендотелію, який безпосередньо пов'язаний яК з ХКС, так і з НАЖХП, $є$ асиметричний диметиларгінін (ADMA) ендогенний інгібітор ферменту NO-синтетази, що каталізує перетворення L-аргініну в окис азоту [17].

На сьогодні актуальним $€$ подальше визначення спільних механізмів прогресування ХКС і НАЖХП з метою вироблення комплексного та індивідуалізованого підходу до ведення хворих з цією коморбідною патологією.

Мета - вивчити рівні адипоцитокінів, маркерів системного запалення та ендотеліальної дис- 
Огляди літератури, оригінальні дослідження, погляд на проблему, випадок з практики, короткі повідомлення функції та їх взаємозв'язок з клінічним перебігом ХКС, коморбідної з НАЖХП.

Матеріал і методи дослідження. У проспективне моноцентрове подвійне відкрите дослідження в паралельних групах залучено 120 хворих на XKС: стабільну стенокардію напруження IIIII функціонального класу віком $60,0(55,0 ; 64,0)$ років, з них 67 (55 \%) чоловіків і 53 (45 \%) жінки. До групи контролю увійшли 30 практично здорових осіб віком 59,0 (58,0; 66,0) років, серед них 14 (46\%) чоловіків і 16 (54 \%) жінок. Дизайн роботи погоджено з Комісією з питань біоетики Запорізького державного медичного університету.

Критерії включення в дослідження: наявність документованого (верифікованого) ХКС: стабільної стенокардії напруження II-III функціонального класу та НАЖХП, письмова інформована згода на участь у дослідженні.

Для забезпечення отримання достовірних результатів дослідження були розроблені критерії виключення з дослідження: алкогольна хвороба чи цироз печінки, автоімунні та вірусні гепатити; вроджені чи набуті вади серця; серцева недостатність III-IV функціонального класу за NYHA; інфаркт міокарда (гострий, підгострий періоди), нестабільна стенокардія; інфекційні захворювання в гострому періоді; бронхіальна астма або ХОЗЛ; анемія (Нb <90 г/л); гіпотиреоз; хронічні захворювання внутрішніх органів у період загострення та в стадії декомпенсації; наявність онкологічних, психічних захворювань.

Усі обстежені особи, які взяли участь у дослідженні, початково були поділені на 2 групи: 1 група (основна) - 60 хворих на ХКС із супутньою НАЖХП (стеатоз або стеатогепатит); 2 група (порівняння) - 60 хворих на ХКС без супутньої НАЖХП. Для визначення референтних значень показників, що вивчалися, як контрольні використовувалися дані, отримані у 30 практично здорових осіб, які були зіставні за віком і статевою належністю, без захворювань серцево-судинної системи і печінки.

Діагноз ХКС і функціонального класу стабільної стенокардії ґрунтувався на комплексному аналізі скарг, даних фізикального обстеження, результатах лабораторних та інструментальних досліджень згідно з Національними стандартами. Компоненти метаболічного синдрому у хворих на ХКС визначались за критеріями IDF (2009р.). Діагноз НАЖХП встановлювали відповідно до критеpiїв World Gastroenterology Organization Global Guidelines, адаптованої клінічної настанови «Неалкогольна жирова хвороба печінки» (2014р.) та уніфікованого клінічного протоколу первинної, вторинної (спеціалізованої) медичної допомоги «Неалкогольний стеатогепатит» (2014р.) після

виключення іншої етіології ураження печінки. 3 цією метою визначали маркери вірусних гепатитів, проводили Fast-тест - швидкий алкогольний скринінговий тест (для визначення ймовірності зловживання алкоголем), тест Fibromax (для виключення вірусної, автоімунної, алкогольної етіології ураження печінки, визначення ступеня ії стеатозу та фіброзу) або пункційна біопсія печінки (для виключення інших причин ураження печінки та оцінки стадії фіброзу) за необхідності. Хворих з діагностованим неалкогольним стеатогепатитом (НАСГ) скеровували на консультацію до лікаря-гастроентеролога.

На 1-3 добу перебування в стаціонарі проводили комплексне клінічне обстеження з урахуванням скарг, даних анамнезу, об'єктивних і додаткових (лабораторних та інструментальних) методів дослідження згідно із загальноприйнятими стандартами. Визначення вмісту біомаркерів у сироватці крові виконували на базі Навчального медико-лабораторного центру Запорізького державного медичного університету на імуноферментному повноплашковому аналізаторі «SIRIO S» (Італія). Рівень інсуліну в сироватці крові досліджували за допомогою набору реактивів виробництва фірми Monobind (USA); асиметричного диметиларгініну-фірми Immundiagnostik (Germany); адипонектину і резистину - фірми Mediagnost (Germany); СРБ - фірми Biomerica (USA); рівні гамма-глутамілтрансферази (ГГТ) і лужної фосфатази (ЛФ) визначали фотометричним методом 3 використанням наборів реактивів PLIVA-Lachema Diagnostika (Чеська республіка) згідно з інструкціями, що додавались до набору. Індекси HOMA та CARO розраховували за загальноприйнятими формулами.

Статистичну обробку даних проводили із застосуванням пакета ліцензійної програми "Statistica 13.0»(StatSoftInc, США, № JPZ8041382130ARCN10-J). Гіпотезу про нормальність розподілу досліджуваних показників перевіряли з використанням критерію Шапіро - Уїлка. Кількісні ознаки були представлені у вигляді $\mathrm{M} \pm \mathrm{m}$ (середнє арифметичне \pm стандартна похибка середнього арифметичного) а6о Ме (Q25; Q75) (медіана, 25 і 75 перцентиль), залежно від виду розподілу. При нормальному розподілі достовірність відмінностей оцінювали за допомогою t-критерію Стьюдента для незалежних вибірок. При розподілі, що відрізняється від нормального, використовували непараметричні критерії: U-критерій Манна - Уїтні для незалежних вибірок. Для оцінки взаємозв'язків між показниками використовували метод кореляційного аналізу 3 обчисленням коефіцієнтів кореляції Пірсона (при нормальному розподілі) і Спірмена (при розподілі, що відрізняється від нормального).

Результати й обговорення. Клінічна характеристика хворих представлена в таблиці 1. 
Огляди літератури, оригінальні дослідження, погляд на проблему, випадок з практики, короткі повідомлення Таблиця 1. Клінічна характеристика груп хворих на хронічний коронарний синдром залежно від наявності супутньої неалкогольної жирової хвороби печінки

\begin{tabular}{|c|c|c|}
\hline Показник, одиниці вимірювання & $\begin{array}{c}1 \text { група } \\
\text { ХКС та НАЖХП } \\
(n=60)\end{array}$ & $\begin{array}{c}2 \text { група } \\
\text { ХКС } \\
(n=60)\end{array}$ \\
\hline Вік, роки & $58(44 ; 64)$ & $60,5(54 ; 68)$ \\
\hline САТ, мм рт. ст. п & $160(160 ; 180)$ & $130(130 ; 140)$ \\
\hline ДАТ, мм рт. ст. п & $100(90 ; 100)$ & $90(65 ; 100)$ \\
\hline ЧСС, уд./хв. п & $70,5(61,0 ; 75,0)$ & $69(64 ; 77)$ \\
\hline Тривалість ХКС, роки & $5(4 ; 7)$ & $5(3 ; 7)$ \\
\hline Тривалість НАЖХП, роки & $4(1 ; 9)$ & - \\
\hline Інфаркт міокарда в анамнезі, n/ \% & $15 / 25$ & $12 / 20$ \\
\hline Цукровий діабет 2 типу, n/ \% & $29 / 48,3$ & $26 / 43,3$ \\
\hline Гіпертонічна хвороба, n/ \% & $49 / 81,6$ & $45 / 75$ \\
\hline Ожиріння, п/ \% п & $39 / 65$ & $33 / 55$ \\
\hline Куріння, п/\% п & $13 / 21,66$ & $16 / 26,6$ \\
\hline Дисліпідемія, n/\% п & $30 / 50 *$ & $20 / 35$ \\
\hline Обтяжена спадковість, n/ \% & $34 / 56,6$ & $30 / 50$ \\
\hline
\end{tabular}

Примітки: $1 .{ }^{*}$ - вірогідність різниці показників порівняно з хворими на ХКС та НАЖХП і без патології печінки, за критерієм $\chi^{2}(\mathrm{p}<0,05) ; 2$. Дані наведені у вигляді $\mathrm{Me}\left(\mathrm{Q}_{25} ; \mathrm{Q}_{75}\right)$ або абс./ \%

За віком хворі були зіставні між собою; за даними об'єктивного обстеження, рівні САТ, ДАТ, ЧСС у порівнюваних групах статистично не відрізнялись один від одного. Згідно з анамнестичними даними, статистично значущих відмінностей щодо середньої тривалості ХКС, наявності перенесеного інфаркту міокарда між групами хворих не виявлено. Встановлено, що серед пацієнтів основної групи на 43,59 \% більше хворих, що мають дисліпідемію $\left(\chi^{2}=5,32 ; d f=1 ; p<0,05\right)$. Досто- вірної різниці між двома групами за частотою виявлення інших факторів ризику не встановлено.

За даними морфофункціонального дослідження печінки у 45 (75\%) хворих виявлений стеатоз S2S3 стадії за шкалою METAVIR, у 15 (25\%) - стеатогепатит мінімального ступеня активності. Фіброз печінки відповідав стадії F0-F2 за шкалою METAVIR.

Рівні адипонектину та резистину у хворих на ХКС залежно від наявності НАЖХП представлені на рисунку 1.
Адипонектин

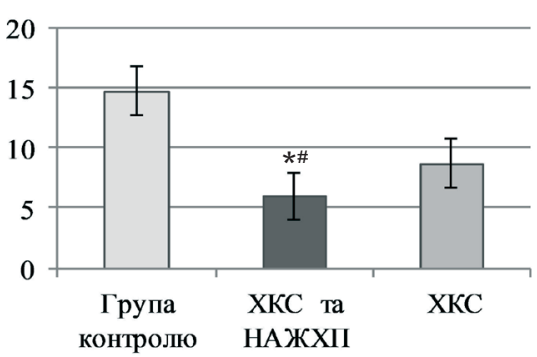

Резистин

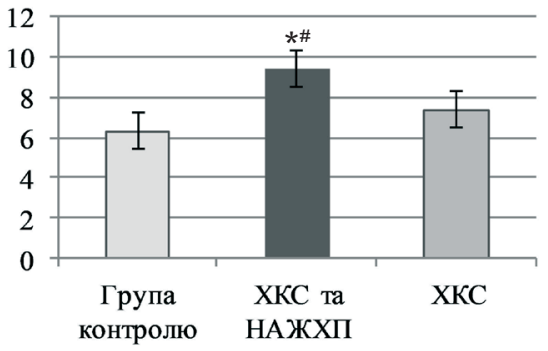

Адипонектин/резистин

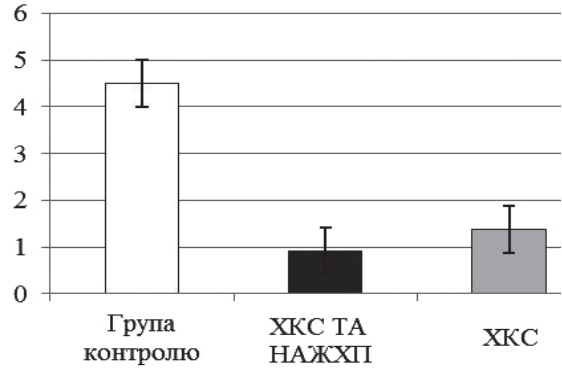

Примітки: 1. * - вірогідність різниці показників порівняно з контрольною групою. 2. \#- вірогідність різниці показників порівняно з хворими на ХКС.

Рис. 1. Концентрація адипонектину, резистину та їх співвідношення у пацієнтів із хронічним коронарним синдромом залежно від наявності супутньої неалкогольної жирової хвороби печінки.

Виявлено дисбаланс рівня адипоцитокінів у хворих на ХКС у поєднанні з НАЖХП. Сироватковий рівень адипонектину у хворих на ХКС з НАЖХП був на $60 \%$ нижчим, ніж у здорових осіб $(p<0,05)$, та на $31,6 \%$ нижчим, ніж у групі порівняння, тоді як рівень резистину був на $48 \%$ вищим, ніж в групі контролю, та на $27 \%$ вищим, ніж у групі порівняння $(p<0,05)$. При цьому хворі на
ХКС без НАЖХП за рівнями адипонектину та резистину суттєво не відрізнялись від здорових осіб. У хворих основної групи спостерігалось суттєве зменшення співвідношення адипоцитокінів: показник адипонектин/резистин був меншим у 1,48 раза, порівняно з хворими на ХКС без патології печінки, та у 4,89 раза, порівняно зі здоровими особами $(p<0,05)$. 
Огляди літератури, оригінальні дослідження, погляд на проблему, випадок з практики, короткі повідомлення

Показники ендотеліальної дисфункції у хворих на ХКС залежно від наявності НАЖХП представлено у таблиці 2.

Виявлено, що у хворих на ХКС із супутньою НАЖХП сироватковий рівень ADMA був на $42 \%$ вищим, ніж у здорових осіб, та на $21 \%$ вищим, порівняно з групою хворих на ХКС без патології пе- чінки ( $<<0,05) ;$ за рівнем СРБ хворі основної групи переважали групу контролю у 8,9 раза та групу порівняння у 2,81 раза ( $<<0,05)$. Поряд з цим, у хворих з НАСГ активність системного запалення була вірогідно більшою, порівняно з хворими зі стеатозом (рис. 2), що підтверджується підвищенням концентрації СРБ на $44 \%$ ( $p<0,05)$.

Таблиця 2. Зміни маркерів системного запалення та ендотеліальної дисфункції у хворих на хронічний коронарний синдром залежно від наявності супутньої неалкогольної жирової хвороби печінки, $\left.\mathrm{Me}_{(25} ; \mathrm{Q}_{75}\right)$

\begin{tabular}{|c|c|c|c|}
\hline $\begin{array}{c}\text { Показник, одиниці } \\
\text { виміру }\end{array}$ & $\begin{array}{c}\text { Контрольна група } \\
(\mathrm{n}=30)\end{array}$ & $\begin{array}{c}1 \text { група } \\
\text { ХКС та НАжХП } \\
(\mathrm{n}=60)\end{array}$ & $\begin{array}{c}2 \text { група } \\
\text { ХКС } \\
(\mathrm{n}=60)\end{array}$ \\
\hline СРБ, мг/л & $\begin{array}{c}0,6 \\
(0,4 ; 0,8)\end{array}$ & $\begin{array}{c}5,3 \\
(3,9 ; 7,9)^{\# *}\end{array}$ \\
\hline ADMА, мкмоль/л & 0,50 & 0,86 & $0,71,2,5)^{*}$ \\
& $(0,44 ; 0,53)$ & $(0,84 ; 0,96)^{\# *}$ & $(0,63 ; 0,76)^{*}$ \\
\hline
\end{tabular}

Примітки: 1. * - вірогідність різниці показників порівняно з контрольною групою $(p<0,05) ; 2$. - вірогідність різниці показників порівняно з хворими на ХКС $(p<0,05)$.

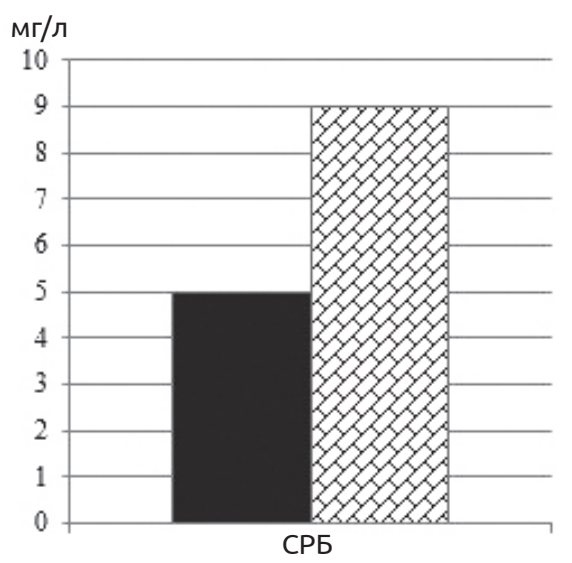

ХКС та стеатоз печінки च ХКС та НАЖХП

Рис. 2. Рівень СРБ у хворих на ХКС та НАЖХП залежно від активності запального процесу у печінці.

Отже, у хворих на ХКС, асоційовану з неалкогольною жировою хворобою печінки, спостерігається дисбаланс адипоцитокінів: зменшення концентрації адипонектину, збільшення рівня резистину та зменшення співвідношення адипонектин до резистину, порівняно з контрольною групою та з хворими на ХКС без патології печінки. Достовірне зростання сироваткового рівня асиметричного диметиларгініну та СРБ у хворих основної групи свідчить про наявність дисфункції ендотелію на тлі активації системного запалення і може вказувати на патогенетичне значення цих маркерів у розвитку та прогресуванні ХКС на тлі НАЖХП.

При проведенні кореляційного аналізу рівнів адипоцитокінів, маркерів дисфункції ендотелію 3 метаболічними порушеннями у хворих на ХКС, коморбідну з НАЖХП, виявлено достовірний прямий сильний зв'язок рівня адипонектину з концентрацією ХС ЛПВЩ $(r=+0,72 ; p<0,05)$ та зворотний зв'язок середньої сили з концентрацією $3 Х С$ ( $r=-0,57$; $p<0,05)$, XС лПнЩ $(r=-0,44 ; p<0,05)$, рівнем триглі- церидів ( $r=-0,59 ; p<0,05)$, індексом атерогенності $(r=-0,50 ; p<0,05)$. Зростання рівня резистину було асоційовано з підвищенням рівнів інсуліну ( $r=+0,42$; $p<0,05)$, глюкози $(r=+0,59 ; p<0,05)$ та індексу атерогенності ( $r=+0,54 ; p<0,05)$. Асиметричний диметиларгінін прямим зв'язком середньої сили пов'язаний із рівнем $3 X C(r=+0,53 ; p<0,05)$, концентрацією інсуліну $(r=+0,43 ; p<0,05)$ та індексом НОМА $(r=+0,49 ; p<0,05)$. Достовірного зв'язку рівня СРБ $з$ антропометричними параметрами, показниками вуглеводного та ліпідного обмінів не встановлено. Виявлено кореляційні зв'язки між рівнями СРБ та АЛТ ( $r=+0,51 ; p<0,05)$, адипонектину і ГГТ ( $r=-0,48$; $p<0,05)$, резистину і ЛФ ( $r=+0,48 ; p<0,05)$, ADMA i ЛФ ( $r=+0,63 ; p<0,05)$, що свідчить про взаємозв'язок дисбалансу адипоцитокінів, дисфункції ендотелію, системного запалення з індикаторами ураження печінки.

При вивченні адипоцитокінового профілю нами встановлена наявність дисбалансу адипоцитокінів у хворих на ХКС у поєднанні з НАЖХП, що 
Огляди літератури, оригінальні дослідження, погляд на проблему, випадок з практики, короткі повідомлення може мати важливе значення в прогресуванні цих поєднаних захворювань. Ряд досліджень свідчать про клінічну значущість гіпоадипонектинемії як фактора ризику розвитку серцево-судинної патології. Доведено, що низький рівень адипонектину $\epsilon$ незалежним фактором ризику для ХКС із НАЖХП [18]. Клінічними дослідженнями встановлено, що у пацієнтів із НАЖХП рівень адипонектину знижений і обернено корелює 3 вираженістю запалення та пошкодження печінки, а також доведено, що адипонектин знижує ступінь стеатозу при висококалорійній дієті, ожирінні, інсулінорезистентності [19].

Взаємозв'язок резистину з компонентами метаболічного синдрому та його роль при НАЖХП вивчались у ряді досліджень. Так, А. Т. Тепляков і співавт. (2015) висловили припущення, що тривале існування резистин-індукованого запалення відіграє істотну роль у розвитку інсулінорезистентності [20]. Виявлено позитивний кореляційний зв'язок між ступенем ожиріння, інсулінорезистентністю та підвищенням рівня резистину $[7,8,21]$. Аналіз вищенаведених даних доводить роль адипоцитокінів як при кардіологічній патології, так і при НАЖХП, проте нині бракує досліджень щодо вивчення змін цих біомаркерів при ХКС із супутньою НАЖХП.

У нашому дослідженні виявлено взаємозв'язок дисфункції ендотелію з метаболічними порушеннями у хворих на НАЖХП, що також було продемонстровано в роботах інших науковців. Доведено, що порушення вуглеводного обміну, IP та ожиріння $\epsilon$ важливими чинниками виникнення дисфункції ендотелію і раннього судинного старіння. Виявлено, що розвиток ендотеліальної дисфункції і підвищення артеріальної жорсткості

$\epsilon$ універсальною відповіддю тканин на інсулінорезистентність і запальний стрес, які властиві як ХКС, так і НАЖХП [22].

Нами також встановлена наявність взаємозв'язку маркера ендотеліальної дисфункції ADMA та основних індикаторів ураження печінки у хворих на ХКС, поєднану з НАЖХП: ЛФ, АЛТ, що узгоджується з даними літератури. В дослідженнях простежується взаємозв'язок маркерів пошкодження ендотелію та індикаторів холестатичного, цитолітичного синдромів [7]. Встановлено, що маркери ендотеліальної дисфункції прогресивно погіршуються зі збільшенням тяжкості ураження печінки [16].

Отже, у хворих на ХКС, коморбідний з НАЖХП, адипоцитокіновий дисбаланс та ендотеліальна дисфункція асоціюються з компонентами метаболічного синдрому.

Висновки. 1. У хворих на ХКС із НАЖХП, порівняно з хворими на ХКС без патології печінки, виявлено збільшення сироваткового рівня резистину, ADMA, СРБ, зменшення концентрації адипонектину та співвідношення адипонектин/резистин.

2. У хворих на ХКС, коморбідну з НАЖХП, адипоцитокіновий дисбаланс та ендотеліальна дисфункція асоціюються з компонентами метаболічного синдрому - дисліпідемією та інсулінорезистентністю.

3. Кореляційні зв'язки між рівнями СРБ та АЛТ, адипонектину і ГГТ, резистину і ЛФ, ADMA і ЛФ свідчать про взаємозв'язок дисбалансу адипоцитокінів, дисфункції ендотелію, системного запалення з індикаторами ураження печінки.

Перспективним $\epsilon$ вивчення можливостей фармакологічної корекції виявлених порушень у хворих на ХКС з супутньою НАЖХП.

\section{ЛІТЕРАТУРА}

1. Чекаліна Н. І. Гендерний аналіз показників хронічного системного запалення у хворих на ішемічну хворобу серця / Н. І. Чекаліна // Вісник проблем біології і медицини. - 2020. - Вип. 3 (157). - С. 161-165.

2. Jurisch D. Chronisches Koronarsyndrom : Neuklassifikation der stabilen koronaren Herzkrankheit / D. Jurisch, U. Laufs // Der Internist. - 2021. - Vol. 62(1). - P. 47-57.

3. Вірстюк Н. Г. Вплив способу життя на перебіг неалкогольної жирової хвороби печінки у пацієнтів зі стабільною ішемічною хворобою серця / Н. Г. Вірстюк, І. І. Вакалюк // Укр. мед. часопис. - 2017. - № 2. - С. 113-116.

4. Бабінець Л.С. Взаємозалежність стану печінки і підшлункової залози при хронічному біліарному панкреатиті на тлі ожиріння. Підходи до комплексного лікування / Л. С. Бабінець, К. Ю. Кицай // Сучасна гастроентерологія. - 2021. - № 1 (117). - С. 5-11.

5. Do A. Epidemiology of nonalcoholic fatty liver disease: A primer / A. Do., J. Lim // Clinical Liver Disease.2016.- Vol. 7(5). - P. 106-108.

6. Степанов Ю. М. Еволюція уявлень про неалкогольну жирову хворобу печінки: від ризику до катастрофи / Ю. М. Степанов, О. Ю. Філіппова // Запорожский медицинский журнал. - 2020. - Т. 22, № 2 (119). С. 267-274.

7. Неалкогольна жирова хвороба печінки: особливості метаболічних змін на різних етапах розвитку хвороби / Ю. М. Степанов, Н. В. Недзвецька, В. Б. Ягмур, І. А. Кленіна // Гастроентероглогия. - 2018. - № 152 (1). С. 1-6.

8. Михайловська Н. С. Взаємозв'язок неалкогольної жирової хвороби печінки з компонентами метаболічного синдрому у хворих на ішемічну хворобу серця / 
Огляди літератури, оригінальні дослідження, погляд на Н. С. Михайловська, Л. Є. Міняйленко // Буковинський мед. вісник. - 2016. - № 1 (77). - С. 79-83.

9. The pathologic relevance of metabolic criteria in patients with biopsy-proven non-alcoholic fatty liver disease and metabolic dysfunction associated fatty liver disease: A multicenter cross-sectional study in China / R. X. Yang, Z. S. Zou, B. H. Zhong [et al.] // Hepatobiliary \& pancreatic diseases international : HBPD INT. - 2021. S1499-3872. Advance online publication. https://doi. org/10.1016/j.hbpd.2021.06.002

10. Benedict M. Non-alcoholic liver disease: An expanded review / M. Benedict, X. Zhang // World J. Hepatol. 2017. - Vol. 9(16). - P. $715-732$.

11. Mykhailovska N. S. Vascular endothelium state, clinical and metabolic features of patients with coronary heart disease combined with nonalcoholic fatty liver disease / N. S. Mykhailovska, L. E. Miniailenko // Патологія. 2017. - № 1. - C. 62-67.

12. Nonalcoholic fatty liver disease or metabolic dysfunction-associated fatty liver disease diagnoses and cardiovascular diseases: From epidemiology to drug approaches / P. Dongiovanni, E. Paolini, A. Corsini [et al.] // European journal of clinical investigation. - 2021. - 51 (7). P. e13519. https://doi.org/10.1111/eci.13519

13. Ткач С. М. Неалкогольна жирова хвороба печінки: поширеність, природний перебіг, сучасні підходи до діагностики та лікування / С. М. Ткач, Т. Л. Чеверда // Клінічна ендокринологія та ендокринна хірургія. 2016. - № 1. - С. 60-71

14. Achari A. E. Adiponectin, a Therapeutic Target for Obesity Diabetes, and Endothelial Dysfunction / A. E. Achari, S. K. Jain // International Journal of Molecular Sciences. - 2017. - Vol. 18(6). - P. 1 - 17.

15. The effect of adiponectin in the pathogenesis of non-alcoholic fatty liver disease (NAFLD) and the potential role of polyphenols in the modulation of adiponectin signaling / S. C. Shabalala, P. V. Dludla, L. Mabasa [et al.] // Biomedicine \& pharmacotherapy $=$ Biomedecine $\&$ pharmacotherapy. - 2020. - Vol. 131, - P. 110785. https://doi.org/ 10.1016/j.biopha.2020.110785

16. Non-Alcoholic Fatty Liver Disease and Vascular Disease / R. Forlano, B. H. Mullish, R. Nathwani [et al.] // Current vascular pharmacology - 2021. - Vol. 19(3). - P. 269-279. https://doi.org/10.2174/1570161118666200318103001

17. L-Arginine-Nitric Oxide-Asymmetric Dimethylarginine Pathway and the Coronary Circulation: Translation of Basic Science Results to Clinical Practice / A. Cziráki, Z. Lenkey, E. Sulyok [et al.] // Frontiers in pharmacology. - 2020. Vol.11.-P.569914.https://doi.org/10.3389/fphar.2020.569914

18. Low serum adiponectin is a predictor of progressing to nonalcoholic fatty liver disease / H. Zhang, Y. Niu, H. Gu [et al.] // Journal of clinical laboratory analysis. 2019. - Vol. 33(3). - P. e22709. https://doi.org/10.1002/ jcla.22709

19. Clinical and metabolic characterization of obese subjects without non-alcoholic fatty liver: A targeted metabolomics approach / A. Feldman, S. K. Eder, T. K. Felder [et al.] // Diabetes \& metabolism. - 2019. - Vol. 45(2). P. 132-139. https://doi.org/10.1016/j.diabet.2018.09.003

20. Влияние резистина на течение ишемической болезни сердца у пациентов с сахарным диабетом 2-го типа / А. Т. Тепляков, Ш. Д. Ахмедов, Т. Е. Суслова [и др.] // Бюл. сиб. медицины. - 2015. - № 14 (5). - С. 73-82.

21. Acute Elevated Resistin Exacerbates Mitochondrial Damage and Aggravates Liver Steatosis Through AMPK/ PGC-1 $\alpha$ Signaling Pathway in Male NAFLD Mice / F. Wen, Z. Shi, X. Liu [et al.] // Hormone and metabolic research = Hormon- und Stoffwechselforschung $=$ Hormones et metabolism. - 2021. - Vol. 53(2). - P. 132-144. https://doi. org/10.1055/a-1293-8250

22. Insulin resistance, cardiovascular stiffening and cardiovascular disease / M. A. Hill, Y. Yang L., Zhang [et al.] // Metabolism: clinical and experimental. - 2021. - Vol. 119. 154766. https://doi.org/10.1016/j.metabol.2021.154766

\section{REFERENCES}

1. Chekalina, N.I. (2020). Hendernyi analiz pokaznykiv khronichnoho systemnoho zapalennia u khvorykh na ishemichnu khvorobu sertsia [Gender analysis of chronic systemic inflammation indicators in patients with ischemic heart disease] Visnyk problem biolohii i medytsyny - Bulletin of Problems of Biology and Medicine, 3 (157), 161-165 [in Ukrainian].

2. Jurisch, D., \& Laufs, U. (2021). Chronisches Koronarsyndrom : Neuklassifikation der stabilen koronaren Herzkrankheit. Der Internist, 62(1), 47-57. https://doi. org/10.1007/s00108-020-00910-0

3. Virstiuk, N.H., \& Vakaliuk, I.I. (2017). Vplyv sposobu zhyttia na perebih nealkoholnoi zhyrovoi khvoroby pechinky u patsiientiv zi stabilnoiu ishemichnoiu khvoroboiu sertsia [The influence of lifestyle on the course of non-alcoholic fatty liver disease in patients with stable coronary heart disease]. Ukr. med. Chasopys - Ukr. Med. Magazine, 2, 113 - 116 [in Ukrainian].

4. Babinets, L.S., \& Kytsai, K.lu., (2021). Vzaiemozalezhnist stanu pechinky i pidshlunkovoi zalozy pry

khronichnomu biliarnomu pankreatyti na tli ozhyrinnia. Pidkhody do kompleksnoho likuvannia [Interdependence of the state of the liver and pancreas in chronic biliary pancreatitis on the background of obesity. Approaches to complex treatment]. Suchasna hastroenterolohiia-Modern Gastroenterology, 1(117), 5-11 [in Ukrainian].

5. Do, A., \& Lim, J.K. (2016). Epidemiology of nonalcoholic fatty liver disease: A primer. Clinical Liver Disease, 7(5), 106-108. https://doi.org/10.1002/cld.547

6. Stepanov, Yu.M., \& Filippova, O.Yu., (2020). Evoliutsiia uiavlen pro nealkoholnu zhyrovu khvorobu pechinky: vid ryzyku do katastrofy [Evolving ideas on nonalcoholic fatty liver disease: from risk to catastrophe]. Zaporozhskyi medytsynskyi zhurnal - Zhaporizhzhia Medical Journal, 22, 2(119), 267-274 [in Ukrainian].

7. Stepanov, Yu.M., Nedzvetska, N.V., Yahmur, V.,B., \& Klenina, I.A. (2018). Nealkoholna zhyrova khvoroba pechinky: osoblyvosti metabolichnykh zmin na riznykh etapakh rozvytku khvoroby [Non-alcoholic fatty liver disease: features of metabolic changes at different stages 
Огляди літератури, оригінальні дослідження, погляд на проблему, випадок з практики, короткі повідомлення of the disease]. Hastroenterohlohiya-Gastroenterology, 1, 52(1), 1-6 [in Ukrainian].

8. Mykhailovska, N.S., \& Miniailenko, L.le. (2016). Vzaiemozviazok nealkoholnoi zhyrovoi khvoroby pechinky z komponentamy metabolichnoho syndromu u khvorykh na ishemichnu khvorobu sertsia. [Relationship of nonalcoholic fatty liver disease with components of metabolic syndrome in patients with ischemic heart disease]. Bukovynskyi med. Visnyk - Bukovinian Med. Bulletin, 1 (77), 79-83 [in Ukrainian].

9. Yang, R.X., Zou, Z.S., Zhong, B.H., Deng, H., He, F.P., Shi, J.P., Zhao, C.Y., Mi, Y.Q., Zhou, Y.J., Di, F.S., Zheng, R.D., Du, Q., Shang, J., Popovic, B., Chen, J., \& Fan, J.G. (2021). The pathologic relevance of metabolic criteria in patients with biopsy-proven non-alcoholic fatty liver disease and metabolic dysfunction associated fatty liver disease: A multicenter cross-sectional study in China. Hepatobiliary \& Pancreatic Diseases International : HBPD INT, 1499-3872(21)001120 . Advance online publication. https://doi.org/10.1016/j. hbpd.2021.06.002

10. Benedict, M., \& Zhang, X. (2017). Non-alcoholic fatty liver disease: An expanded review. World Journal of Hepatology, 9(16), 715-732. https://doi.org/10.4254/wjh.v9.i16.715

11. Mykhailovska, N.S., \& Miniailenko, L.E. (2017). Vascular endothelium state, clinical and metabolic features of patients with coronary heart disease combined with nonalcoholic fatty liver disease. Patolohiia - Pathology, 1, $62-67$ [in Ukrainian].

12. Dongiovanni, P., Paolini, E., Corsini, A., Sirtori, C.R., \& Ruscica, M. (2021). Nonalcoholic fatty liver disease or metabolic dysfunction-associated fatty liver disease diagnoses and cardiovascular diseases: From epidemiology to drug approaches. European Journal of Clinical Investigation, 51(7), e13519. https://doi.org/10.1111/eci.13519

13. Tkach, S.M., \& Cheverda, T.L. (2016). Nealkoholna zhyrova khvoroba pechinky: poshyrenist, pryrodnyi perebih, suchasni pidkhody do diahnostyky ta likuvannia. [Nonalcoholic fatty liver disease: incidence, natural history, new approaches to diagnostic and treatment]. Klinichna endokrynolohiia ta endokrynna khirurhiia - Clinical Endocrinology and Endocrine Surgery, 1, 60-71 [in Ukrainian].

14. Achari, A.E., \& Jain, S.K. (2017). Adiponectin, a Therapeutic Target for Obesity, Diabetes, and Endothelial Dysfunction. International Journal of Molecular Sciences, 18(6), 1321. https://doi.org/10.3390/ijms18061321

15. Shabalala, S.C., Dludla, P.V., Mabasa, L., Kappo, A.P., Basson, A.K., Pheiffer, C., \& Johnson, R. (2020). The effect of adiponectin in the pathogenesis of non-al-

coholic fatty liver disease (NAFLD) and the potential role of polyphenols in the modulation of adiponectin signaling. Biomedicine \& Pharmacotherapy = Biomedecine \& Pharmacotherapie, 131, 110785. https://doi.org/10.1016/j.biopha.2020.110785

16. Forlano, R., Mullish, B.H., Nathwani, R., Dhar, A., Thursz, M.R., \& Manousou, P. (2021). Non-Alcoholic Fatty Liver Disease and Vascular Disease. Current Vascular Pharmacology, 19(3), 269-279. https://doi.org/10.2174/157016 1118666200318103001

17. Cziráki, A., Lenkey, Z., Sulyok, E., Szokodi, I., \& Koller, A. (2020). L-Arginine-Nitric Oxide-Asymmetric Dimethylarginine Pathway and the Coronary Circulation: Translation of Basic Science Results to Clinical Practice. Frontiers in Pharmacology, 11, 569914. https://doi. org/10.3389/fphar.2020.569914

18. Zhang, H., Niu, Y., Gu, H., Lu, S., Zhang, W., Li, X., Yang, Z., Qin, L., \& Su, Q. (2019). Low serum adiponectin is a predictor of progressing to nonalcoholic fatty liver disease. Journal of Clinical Laboratory Analysis, 33(3), e22709. https://doi.org/10.1002/jcla.22709

19. Feldman, A., Eder, S.K., Felder, T.K., Paulweber, B., Zandanell, S., Stechemesser, L., Schranz, M., Strebinger, G., Huber-Schönauer, U., Niederseer, D., Patsch, W., Weghuber, D., Tevini, J., Datz, C., \& Aigner, E. (2019). Clinical and metabolic characterization of obese subjects without non-alcoholic fatty liver: A targeted metabolomics approach. Diabetes \& Metabolism, 45(2), 132-139. https://doi. org/10.1016/j.diabet.2018.09.003

20. Tepliakov, A.T., Akhmedov, Sh.D., \& Suslova, T.E. (2015). Vlyianye rezystyna na techenye yshemycheskoi bolezny serdtsa u patsyentov s sakharnbm dyabetom 2-ho typa [Effect of resistin on the course of ischemic heart disease in patients with type 2 diabetes mellitus] Biul.syb. medytsyny - Bul. Sib. Medicine., 14 (5), 73-82 [in Russian].

21. Wen, F., Shi, Z., Liu, X., Tan, Y., Wei, L., Zhu, X., Zhang, H., Zhu, X., Meng, X., Ji, W., Yang, M., \& Lu, Z. (2021). Acute Elevated Resistin Exacerbates Mitochondrial Damage and Aggravates Liver Steatosis Through AMPK/PGC$1 \alpha$ Signaling Pathway in Male NAFLD Mice. Hormone and Metabolic Research = Hormon- und Stoffwechselforschung = Hormones et Metabolisme, 53(2), 132-144. https:// doi.org/10.1055/a-1293-8250

22. Hill, M.A., Yang, Y., Zhang, L., Sun, Z., Jia, G., Parrish, A.R., \& Sowers, J.R. (2021). Insulin resistance, cardiovascular stiffening and cardiovascular disease. Metabolism: Clinical and Experimental, 119, 154766. https://doi. org/10.1016/j.metabol.2021.154766

\title{
NEUROHUMORAL DISORDERS IN PATIENTS WITH CHRONIC CORONARY SYNDROME COMORBID WITH NON-ALCOHOLIC FATTY LIVER DISEASE
}

\author{
@N. S. Mykhailovska, L. Ye. Miniailenko, O. O. Lisova, T. O. Kulynych, \\ A. V. Grytsay, O. V. Shershniova, I. O. Stetsiuk
} Zaporizhzhia State Medical University

SUMMARY. Non-alcoholic fatty liver disease is considered to be one of the conditions associated with the metabolic syndrome, which significantly worsens the course of chronic coronary syndrome (CCS).

The aim - to study the levels of adipocytokines, markers of systemic inflammation and endothelial dysfunction and their relationship with the clinical course of ACS, comorbid with non-alcoholic fatty liver disease (NAFLD). 
Огляди літератури, оригінальні дослідження, погляд на проблему, випадок з практики, короткі повідомлення

Material and Methods. The prospective monocenter double open study in parallel groups involved 120 patients with CCS: stable angina pectoris II-III functional class aged 60.0 (55.0; 64.0) years, of whom 67 (55\%) men and 53 (45\%) women. The control selected group included 30 healthy individuals aged $59.0(58.0 ; 66.0)$ years, including 14 (46\%) men and 16 (54\%) women. Determination of the serum concentration of biomarkers (adiponectin, resistin, insulin, asymmetric dimethylarginine (ADMA), C-reactive protein) was performed using enzyme-linked immunosorbent assay.

Results. In patients with CCS combined with NAFLD, the derived levels of biomarkers significantly $(p<0.05)$ differed from the control selected group: the concentration of resistin was $48 \%$ higher, adiponectin $60 \%$ lower; there was an increase in the content of CRP (by 8.9 times) and ADMA (by $42 \%$ ). In patients with CCS without liver pathology, the levels of adiponectin and resistin did not significantly exceed those in healthy individuals, but there were significantly higher levels of CRP (by 3.1 times) and ADMA (by $30 \%$ ). In patients with CCS combined with NAFLD, if compared to patients with CCS without structural and functional pathology of the liver, a significant $(p<0.05)$ decrease in adiponectin level by $31.6 \%$, an increase in resistin level by $27 \%$, ADMA level by $21 \%$ and CRP level by 2.81 times was observed. In patients with nonalcoholic steatohepatitis (NASH), the activity of systemic inflammation was significantly higher if compared to patients with steatosis, which was confirmed by an increase in CRP concentration by $44 \%(p<0.05)$. The identified correlations reflect the existing relationship between the functional state of the liver and metabolic, neurohumoral disorders.

Conclusions. In patients with CCS associated with NAFLD, there is an imbalance of adipocytokines (decrease in adiponectin concentration, increase in resistin levels and decrease in the ratio of adiponectin to resistin) compared with the control selected group and in patients with CCS without liver pathology. Significant increases in serum levels of ADMA and CRP indicate the presence of endothelial dysfunction on the background of activation of systemic inflammation and may indicate the pathogenetic significance of these markers in the development and progression of CCS on the background of NAFLD.

KEY WORDS: chronic coronary syndrome; non-alcoholic fatty liver disease; adiponectin; resistin; insulin; asymmetric dimethylarginine; C-reactive protein. 